\title{
The Application of Micro-video Teaching Method in College Basketball Class
}

\author{
Wenhui Tan \\ Jiangxi Science and Technology Normal University, School of Physical Education, Nanchang, 330013, \\ China
}

Keywords: micro-video; basketball teaching; college students

\begin{abstract}
Micro-video is a form of teaching through short-time videos which aims to achieve teaching purpose. This paper selects 60 male students randomly from non-basketball major elective classes of Jiangxi Science and Technology Normal University, and conducts a 32-hour basic basketball technique course in 8 weeks. The paper uses many research methods, including literature research, questionnaire, experimental teaching and mathematical statistics. The research findings shows that micro-video teaching can promote students to master a series of basic basketball movements in a faster and more standard way, which makes it has more advantages than traditional teaching method.
\end{abstract}

\section{Introduction}

Micro-video, as a means of information-based teaching, has a tremendous impact on traditional classroom teaching with its intuitive image and rich audio-visual effects. It is an indispensable part of modern classroom teaching. Through micro-video teaching, on the one hand, teachers can reduce the burden of class, so that teachers can have more energy to prepare for lesson and after-school tutoring. Micro-video teaching can attract students' attention, cultivate students' interest in related subjects, and improve students' learning efficiency. Micro-video is currently used in many disciplines, and the academic community has also conducted extensive research on it. However, as far as the author sorts out relevant literature, the current academic circles are still lacking in practical research on the use of micro-video in college basketball teaching. There is not enough data to support it to be more rational and superior to technical action learning than other teaching methods. Therefore, the author hopes to study the effects of micro-video in college basketball lessons through investigations and related experiments, and propose relevant improvement measures to provide reference for the reform of college basketball curriculum.

\section{Research Objects and Methods}

\subsection{Research Objects.}

The research object is the practical research of micro video teaching method in college basketball teaching. The subjects were 60 male students in the public basketball training class of Jiangxi Science and Technology Normal University.

\subsection{Research Methods.}

Questionnaire method. According to the needs of the writing of the thesis, after reading a large number of books and literature related to this thesis,

A questionnaire was developed. After the teaching experiment, in order to test the implementation of the teaching method in the teaching process, the questionnaire "Study on the satisfaction of the implementation of the micro-video teaching method in basketball teaching" was designed. An expert validity test was performed on the test paper.

This study used the repeated test method to conduct a questionnaire reliability test, and the weight of the same questionnaire was performed at different times.

For the complex measurement, the interval between the two measurements was 14 days, and the correlation between the two measurements or the significance test of the difference was used to 
evaluate the reliability of the questionnaire. We randomly conducted a retest reliability test on 10 experts, and the correlation coefficient of the survey questionnaire was retested to be 0.85 , thus proving the results of the survey.

Credibility has a significant meaning. This study uses the expert experience evaluation method, that is, 10 experts from relevant disciplines are invited to evaluate the content and structural validity of the student test papers (6 professors, 4 associate professors), and experts through the content and structural validity of the test papers The overall evaluation results are shown in Table 1.

Table 1 Statistical Table of Experts Evaluation Results of Questionnaire Validity

\begin{tabular}{llllll}
\hline Expert title & $\begin{array}{l}\text { Very } \\
\text { much } \\
\text { agree }\end{array}$ & agree & $\begin{array}{l}\text { Basic } \\
\text { consent }\end{array}$ & disagree & $\begin{array}{l}\text { absolutely } \\
\text { disagree }\end{array}$ \\
\hline professor & 1 & 3 & 2 & \\
Associate & 1 & 2 & 1 & \\
Professor & & & & \\
\hline
\end{tabular}

Teaching experiment method. The micro-video teaching method uses the micro-video teaching resources on the Internet to teach, and can more effectively cultivate students' interest in learning related subjects. Micro-video teaching itself is mainly through some video, audio, animation and other forms of teaching can attract students' attention through sound, images, etc., so that students are completely attracted to it, thus generating interest in basketball; micro the second advantage of video teaching is that it can greatly reduce the teaching burden of related teachers. Micro-video teaching means that teachers can replace their own classroom teaching by downloading some network micro-video teaching resources to play these network micro-video resources. Teachers can focus more on correcting students' technical movements and mastering the learning process in the classroom. The third advantage of micro-video teaching is that it can enrich the teaching forms of related disciplines. One of the goals of the new curriculum reform is to promote the diversification of teaching forms, improve students' interest classes in the classroom, and increase students' interest in classroom learning. The traditional form of classroom teaching is a form of theoretical indoctrination, which is not conducive to students' interest in relevant teaching content. As a kind of teaching form based on Internet resources, micro-video teaching effectively compensates for the single and boring traditional teaching forms, making the classroom atmosphere more lively and vivid, attracting students' attention. Therefore, the micro-video teaching form is an important supplement to the traditional teaching method.

There are two main types of personnel required for the experiment. The first one is the experimental object. This article will randomly select 60 people from the Jiangxi Science and Technology Normal University's public basketball elective course as the experimental object. Second, in order to ensure the scientific nature of the experiment, this article will invite Three basketball experts judged the results of the experiment.

According to the syllabus, the teaching is carried out according to the teaching progress. The experimental period is 8 weeks, 2 lessons per week, 4 hours, a total of 32 hours, and finally the standard and technical test.

In order to ensure the smooth progress of the experiment, before the teaching experiment, the teacher tested the basic skills of the basketball for the students, which ensured the experiment has high validity.

In the experiment, two groups of students conducted teaching experiments and adopted different teaching methods. In the 32-hour teaching experiment, the students in the control group used traditional explanation and demonstration teaching methods to teach. The experimental group students used micro-video teaching on the basis of traditional teaching. In the law, students will preview the actions to be learned in advance through micro-video before learning the technical action. The teaching content and teaching hours of the two groups of students are the same. Both micro-video teaching and traditional teaching are designed to allow students to master technical 
movements and related theoretical knowledge, and to understand and skillfully apply them to practice. In the 32 classes of eight weeks, you should learn the basic skills of four basketballs, learn one technical action every two weeks, and each technical action will be evaluated after the last class. The test method is conducted by the method of separation of teaching and learning. Adopt the assessment method that combines the standard and the technical evaluation.

Before the experiment, the two groups of students were tested for the difference in basic basketball skills. In the teaching process, the two groups were consistent in terms of the number of students, teaching content, and amount of practice. Finally, the expert group will meet the standards and skills tests, and the technical evaluation will be evaluated according to the scoring standards of each technical action.

Mathematical Statistics. The SPSS software was used to perform independent sample T test on the body shape and quality index of the experimenter and the experimental result data. The results were expressed by the mean standard deviation. Find the $\mathrm{P}$ value and test whether there is a significant difference between the experimental group and the control group, and provide an objective basis for the experiment.

\section{Results and Analysis}

\subsection{The Basic Skills Test Results of the Basketball before the Experiment}

Table 2 Pre-test basketball half-court dribble

\begin{tabular}{lllll}
\hline $\begin{array}{l}\text { Test items (Half-time see the } \\
\text { line back to the dribble) }\end{array}$ & $\begin{array}{l}\text { Test Group } \\
\mathrm{M} \pm \mathrm{SD}\end{array}$ & $\begin{array}{l}\text { Control group } \\
\mathrm{M} \pm \mathrm{SD}\end{array}$ & $\mathrm{F}$ & $\mathrm{P}$ \\
\hline $\begin{array}{l}\text { Dribble time (seconds) } \\
\begin{array}{l}\text { Dribble technical evaluation } \\
\text { (minutes) }\end{array}\end{array}$ & $\begin{array}{l}18.40 \pm 1.62 \\
58.47 \pm 5.40\end{array}$ & $\begin{array}{l}18.59 \pm 2.33 \\
58.93 \pm 6.33\end{array}$ & 0.735 & 0.911 \\
\hline
\end{tabular}

Note: $\mathrm{P}>0.05$ has no significant difference, $\mathrm{P}<0.05$ has significant difference, $\mathrm{P}<0.01$ has very significant difference

The data of the half-line dribble reentry test of the pre-test project was analyzed. The results showed that there was no significant difference in the test scores of the project, $\mathrm{F}=0.735, \mathrm{p}>0.05$, and the technical evaluation score was not significant, $F=0.911, p>0.05$. This indicates that the subject's dribbling technique did not reach a statistically significant difference during the pre-test period, which maintained the homogeneity of the dribble technique in the two groups.

Table 3 Pre-test basketball in-situ hand chest pass ball one-minute score statistics table

\begin{tabular}{lllll}
\hline $\begin{array}{l}\text { Test items(hands pass } \\
\text { the ball on the chest) }\end{array}$ & $\begin{array}{l}\text { Test Group } \\
\mathrm{M} \pm \mathrm{SD}\end{array}$ & $\begin{array}{l}\text { Control } \\
\text { group } \\
\mathrm{M} \pm \mathrm{SD}\end{array}$ & $\mathrm{F}$ & $\mathrm{P}$ \\
\hline $\begin{array}{l}\text { Number of times } \\
\text { (times) }\end{array}$ & $40.00 \pm 3.11$ & $40.20 \pm 4.81$ & 5.629 & 0.877 \\
$\begin{array}{l}\text { Technical evaluation } \\
\text { results (minutes) }\end{array}$ & $64.42 \pm 3.02$ & $64.75 \pm 2.77$ & 0.241 & 0.718 \\
\hline
\end{tabular}

Note: $\mathrm{P}>0.05$ has no significant difference, $\mathrm{P}<0.05$ has significant difference, $\mathrm{P}<0.01$ has very significant difference

The one-minute test data of the pre-test project in-situ chest pass ball was analyzed. The results showed that there was no significant difference in the number of successful passes of the project, $\mathrm{F}=5.629, \mathrm{p}>0.05$, the difference in skill evaluation was not Significantly, $\mathrm{F}=0.241, \mathrm{p}>0.05$. This indicates that the skill did not reach a statistically significant difference during the pre-test period, which maintained the homogeneity of the technique of the two groups of subjects in the chest. 


\subsection{The Results of the Test Results and Technical Evaluation of the Experimental Group and the Control Group after the Experiment}

After the experiment, the results of the directional dribble and the technical evaluation results of the experimental group and the control group

Table 4 Statistical table of the forward directional dribble results of the experimental group and the control group

\begin{tabular}{lcllll}
\hline $\begin{array}{l}\text { Test items (change the } \\
\text { dribble in front of the } \\
\text { body) }\end{array}$ & $\begin{array}{c}\text { Test Group } \\
\mathrm{M} \pm \mathrm{SD}\end{array}$ & $\begin{array}{l}\text { Control group } \\
\mathrm{M} \pm \mathrm{SD}\end{array}$ & $\mathrm{T}$ & $\mathrm{P}$ \\
\hline $\begin{array}{l}\text { Time (seconds) } \\
\begin{array}{l}\text { Technical evaluation } \\
\text { results (minutes) }\end{array}\end{array}$ & \begin{tabular}{c}
$13.31 \pm 0.73$ \\
\hline
\end{tabular} & $13.57 \pm 0.35$ & 1.401 & 0.169 \\
\hline
\end{tabular}

Note: $\mathrm{P}>0.05$ has no significant difference, $\mathrm{P}<0.05$ has significant difference, $\mathrm{P}<0.01$ has very significant difference

Table 4 shows that the two groups of students in the forward movement of the dribble scores and technical performance comparison analysis, the experimental group students achieved an average score of 13.31 seconds, the control group achieved an average score of 13.57 seconds, $\mathrm{T}=1.401$, $\mathrm{p}>0.05$, the difference was not significant. In the technical evaluation results, the average score of the technical evaluation of the experimental group was 74.90, and the average score of the technical evaluation of the control group was 69.80, $\mathrm{T}=3.149, \mathrm{p}<0.05$, and there was a significant difference. This shows that the micro-video teaching method is used in the learning of the forward-moving dribbling skills, which is better for the learner's motion evaluation. This is because the experimental group students watch the micro-video in advance before learning the action. There is a certain cognition. There is already some memory before the practice. The control group is cognitive learning after the teacher's explanation and the teacher. It is a passive learning, so the experimental group's learning effect is better, but because of learning the time is short, and in just two weeks, the students are still stuck in the improvement of the action, so there is little difference between the two groups for the test compliance time.

After the experiment, the experimental group and the control group in-situ fixed-point shooting results, technical evaluation results analysis

Table 5 Statistics of the results of passing the ball between the experimental group and the control group

\begin{tabular}{lllll}
\hline $\begin{array}{c}\text { Test items } \\
\begin{array}{l}\text { The two pass the } \\
\text { ball between the two) }\end{array}\end{array}$ & $\begin{array}{l}\text { Test Group } \\
\mathrm{M} \pm \mathrm{SD}\end{array}$ & $\begin{array}{c}\text { Control group } \\
\mathrm{M} \pm \mathrm{SD}\end{array}$ & $\mathrm{T}$ & $\mathrm{P}$ \\
\hline $\begin{array}{l}\text { Time (seconds) } \\
\begin{array}{l}\text { Technical evaluation } \\
\text { results (minutes) }\end{array}\end{array}$ & $\begin{array}{l}17.87 \pm 0.92 \\
78.95 \pm 4.94\end{array}$ & $\begin{array}{l}19.19 \pm 2.20 \\
72.90 \pm 4.20\end{array}$ & 4.173 & 0.000 \\
\hline
\end{tabular}

Note: $\mathrm{P}>0.05$ has no significant difference, $\mathrm{P}<0.05$ has significant difference, $\mathrm{P}<0.01$ has very significant difference

Table 5 shows that the two groups of students passed the ball-to-ball scores and technical evaluation results between the two groups. The scores of the students in the experimental group and the control group were $T=2.423, \mathrm{p}<0.05$, and the difference was significant. In the technical evaluation results, the experimental group and the control group had a significant difference in $\mathrm{T}=2.423, \mathrm{p}<0.05$. This shows that the experimental group used the micro-video teaching method and the traditional teaching method adopted by the control group to learn better when learning the passing skills. This is because the micro-video teaching method is a kind of behavior of students' self-learning. They will take the initiative to discover the essentials of the action, which is more conducive to their further consolidation of the action. In the test of this technical action, there are 
two groups, when the technical movements are generally better, the speed at which they pass the ball is also faster, so there is a significant difference between the experimental group and the control group in the assessment of compliance.

After the experiment, the results of the passing scores and technical evaluations between the experimental group and the control group

Table 6 In-situ fixed-point shooting statistics of the experimental group and the control group

\begin{tabular}{cllll}
\hline $\begin{array}{c}\text { Test items(original } \\
\text { spot shooting) }\end{array}$ & $\begin{array}{l}\text { Test Group } \\
\mathrm{M} \pm \mathrm{SD}\end{array}$ & $\begin{array}{l}\text { Control group } \\
\mathrm{M} \pm \mathrm{SD}\end{array}$ & $\mathrm{T}$ & $\mathrm{P}$ \\
\hline $\begin{array}{l}\text { Number } \\
\begin{array}{l}\text { Technical evaluation } \\
\text { results (minutes) }\end{array}\end{array}$ & $3.00 \pm 0.92$ & $2.85 \pm 0.75$ & 0.567 & 0.574 \\
\hline
\end{tabular}

Note: $\mathrm{P}>0.05$ has no significant difference, $\mathrm{P}<0.05$ has significant difference, $\mathrm{P}<0.01$ has very significant difference

Table 6 shows that the two groups of students in the in-situ fixed-point shooting scores and technical evaluation results comparison analysis, the experimental group and the control group's compliance scores, $\mathrm{T}=0.567, \mathrm{p}>0.05$, the difference is not significant. In the technical evaluation results, the experimental group and the control group in the technical evaluation results, $\mathrm{T}=2.415$, $\mathrm{p}<0.05$, there is a significant difference. This indicates that the experimental group's shooting action is more standardized than the control group, but they are slightly better than the control group in the hit rate, but the difference is not significant. This is because a one-minute shot is a long-term practice and requires special stability. High technical movements, when practiced enough times, can establish a stable action pattern between the degree of exertion and the distance of the shot to improve the hit rate. Based on the short practice time, neither group of participants did not establish a stable action pattern in the shooting technique.

After the experiment, the experimental group and the control group scored low-handed results and technical evaluation results

Table 7 Statistics of low-handed results between the experimental group and the control group

\begin{tabular}{cllll}
\hline $\begin{array}{c}\text { Test items } \\
\text { (handicap shot) }\end{array}$ & $\begin{array}{l}\text { Test Group } \\
\mathrm{M} \pm \mathrm{SD}\end{array}$ & $\begin{array}{l}\text { Control group } \\
\mathrm{M} \pm \mathrm{SD}\end{array}$ & $\mathrm{T}$ & $\mathrm{P}$ \\
\hline $\begin{array}{c}\text { Number } \\
\begin{array}{c}\text { Technical } \\
\text { evaluation } \\
\text { (minutes) }\end{array}\end{array}$ & $4.65 \pm 1.39$ & $4.45 \pm 1.15$ & 0.491 & 0.622 \\
\hline
\end{tabular}

Note: $\mathrm{P}>0.05$ has no significant difference, $\mathrm{P}<0.05$ has significant difference, $\mathrm{P}<0.01$ has very significant difference

Table 6 shows that the two groups of students compared the scores of low-handed scores and technical evaluations during the march. The scores of the experimental group and the control group were compared, $\mathrm{T}=0.491, \mathrm{p}>0.05$, the difference was not significant. In the technical evaluation results, the experimental group and the control group in the technical evaluation results, $\mathrm{T}=2.358$, $\mathrm{p}<0.05$, there is a significant difference. This indicates that the low-handed shots of the experimental group were more standardized than the control group, but they were slightly better than the control group in the above-mentioned hit rate but did not reach significant differences. This is also because the practice time is shorter, and the two groups of subjects are not in the test. A stable action pattern is established in the technique.

\subsection{The Investigation and Analysis of the Teaching Effect of the Micro Video Teaching Method after the Experiment.}

After the end of the experiment, the students in the experimental class will be surveyed for the recognition of teaching methods (see attached questionnaire 1). 30 questionnaires were collected 
and 30 were collected. The survey results are as follows:

The data shows that most students recognize micro-video teaching methods. It is believed that the micro-video teaching method helps it to quickly master the basic skills of basketball technology; it is conducive to students to improve their understanding of the skills before learning; it is conducive to improving students' active participation and enthusiasm; it helps to cultivate students' interest in the subject. From the results of the table, it can be seen that students have a higher affirmation of micro-video feedback teaching and are more willing to accept this new teaching method. However, some students believe that it is not conducive to effective interaction between teachers and students. Micro-video classroom teaching is mainly based on the way of playing related teaching videos. Students are mainly watching video self-study. In this process, the role of teachers is only reflected in the grasp of classroom order, and it is impossible to have too many extras with students. The student's attention is completely attracted by the content presented in the video. This is the advantage of micro-video teaching (that is, it can attract students' attention so as to better improve classroom teaching efficiency). At the same time, the lack of communication between teachers and students is also not conducive to the establishment of a better teacher-student relationship.

\section{Conclusions and Recommendations}

\subsection{Conclusions.}

Through the teaching experiment research, the application research of micro video teaching method in the basic technology teaching of basketball is feasible and effective.

In the assessment of the direction of the dribble in front of the body, the technical performance of the experimental group was better than that of the control group, and there was a significant difference.

In the inter-row pass-through skill assessment, the scores of the experimental group's compliance and technical evaluation were better than the control group, and there was a significant difference. The experimental group's micro-video teaching method learned the effect of passing the ball during the journey. Better than the traditional teaching method of the control group.

In the in-situ shooting and low-hand shooting skills assessment, the technical performance of the experimental group was better than the control group, and there was a significant difference. The micro-video teaching method of the experimental group is more conducive to improving the behavioral norm of the learner.

Using the micro-video teaching method In the basketball technology teaching, the students accept and recognize the teaching method, improve the students' interest in learning, and actively participate in the passive acceptance of learning, which improves the development of students' comprehensive ability.

\subsection{Recommendations.}

Micro-video teaching method For the current situation of college basketball professional teachers, the students can access the complete and standardized technical movements, which lays a foundation for students to form correct technical stereotypes, and also provides a model for students' imitation. .

Micro-video teaching methods also have their own disadvantages, which is not conducive to effective interaction between teachers and students. Therefore, teachers can interact with students after class after using micro-video teaching methods.

Micro-video teaching methods also have a certain cost, so it is necessary to increase the investment in basketball classroom teaching.

Through the above experiments, it can also be found that it can effectively improve the level of basketball teaching. Of course, anything can't be done across the board. Traditional teaching methods have their advantages. They can be combined into micro-video teaching. 


\section{Acknowledgements}

Fund Project: The 13th Five-Year Plan for Education in Jiangxi Province (Project No. 15YB085), Jiangxi Province Higher Education Teaching Reform Project (Project No.: JXJG-17-10-23), Jiangxi University Humanities and Social Sciences Research Project, (Project No.: TY17109)

\section{References}

[1] Sun Shaorong. Educational Information Theory [M]. Shanghai: Shanghai Education Press, 2000

[2] Ma Qiwei. Sports Psychology (M). Higher Education Press, 1995.

[3] Lin Ping. Application of micro video resources in high school physics teaching [D]. Nanjing Normal University, 2014.

[4]Huang Chaocui. Practice of feedback teaching method in rural middle school biology teaching [D]. Guiyang; Guizhou Normal University, 2007

[5] Guo Yandong. On the Application of Feedback in Mathematics Teaching [J]. Educational Science Forum, 2008, (30); 75-76

[6] Qiao Sunxia. How to grasp the suffocation feedback in English teaching. New perspective, 2008, (6); 